\title{
Contribution of the Application of Learning Methods and Learning Activities to the Results of Islamic Religious Education of SMP Swasta Sei Bejangkar
}

\author{
Rusydi Ananda ${ }^{1}$, Muhammad Iskandar ${ }^{2}$ \\ ${ }^{1,2}$ Universitas Islam Negeri Sumatera Utara, Indonesia \\ rusdiananda.1972@gmail.com
}

\begin{abstract}
This study aims to identify and describe: (1) the positive and significant contribution of the application of the learning method to the learning outcomes of Islamic Religious Education, (2) the positive and significant contribution of learning activities to the learning outcomes of Islamic Religious Education, and (3) the positive and significant contribution of the application. Learning methods and learning activities together on the learning outcomes of Islamic Religious Education?.The research was conducted at the Sei Bejangkar Region Private Junior High School. This research is a quantitative study with a correlation research method. The population in this study was all students of class VIII which consisted of 2 classes with a total of 72. All students were used as research samples. The data collection instruments used was questionnaires and tests. The data analysis used is correlation and regression. The research findings show: (1) there is a positive and significant contribution between the application of learning methods and learning outcomes with a correlation number of 0.354 with the regression line equation $\hat{Y}=71.60+0.23 X 1$, (2) there is a positive and significant contribution between learning activities and outcomes. Learn with the correlation number 0.473 with the regression line equation $\hat{Y}=68.96+0.28 \times 2$. and (3) there is a positive and significant contribution between the application of learning methods and learning activities with learning outcomes with a correlation number of 0.549 with the regression line equation $\hat{Y}=138.80+0.18 X 1+0.25 X 2$. The effective contribution of the variable application of learning methods to learning outcomes is 9.90\%, while the effective contribution of learning activity variables to learning outcomes is $20.00 \%$.
\end{abstract}

Keywords

learning methods, learning activities, learning outcomes

\section{Introduction}

Tracing the data in the schools studied showed that the achievement of the minimum completeness criteria had not yet reached the target set in Islamic Religious Education learning of 80.00. The student learning outcomes in the Islamic Religious Education subject have not been encouraging because so far the learning process has not supported student understanding, namely too much material being studied, learning that emphasizes the aspect of memorization, is not equipped with practices in the field. In this case the learning strategy that is applied is not supportive or there is a possibility that it is not in accordance with the material being taught, it may be too monotonous or less varied which can cause the acquisition of student learning outcomes not maximally. 
Education that is carried out from time to time is always changing in accordance with the times. Therefore, teachers as learning managers are required to be more creative and innovative in order to make learning outcomes more optimal. This is in accordance with the Law of the Republic of Indonesia Number 20 of 2003, Article 1 paragraph 19, concerning the National Education System (Sisdiknas) that education is a conscious and planned effort to realize a learning atmosphere and learning process so that students actively develop their potential to have spiritual, religious, self-control, personality, intelligence, noble character, and skills needed by themselves, society, nation and state. (Simorangkir, 2018)

The quality of the education process is determined by a quality learning system approach that aims to teach students and not only concerned with learning outcomes but cannot form fully developed humans. Students must be seen as organisms that are developing and have potential, therefore, active student learning is developed.

The quality of learning can be seen in terms of the process and in terms of results. In terms of the process, learning is said to be of quality and successful if all or at least most of the students are actively involved, both physically, mentally and socially in the learning process. In addition, a quality learning process also shows a high enthusiasm for learning, a high enthusiasm (motivation) for learning, and a sense of self-confidence in students. In other words, learning is said to be of quality and successful if there is a positive change in behavior in all or at least most of the students.

Learning is essentially a cognitive process that has the support of psychomotor functions. The psychomotor function in the learning manifestations carried out by students, almost certainly always involves a function of the realm of reason whose intensity of use is certainly different from other learning events. (Arsani et al, 2020)

The learning method applied in Islamic Religious Education learning is expected to affect the student learning process in an effort to achieve learning outcomes. In this case, one of the duties of the educator or teacher is to create a learning atmosphere that can make students always learn well and be enthusiastic. Such a learning atmosphere will have a positive impact in achieving optimal learning achievement.

Teachers should have the ability to choose the right learning method, in this case the methods meant are methods or techniques that are considered accurate to convey teaching material (Prawiradilaga, 2007: 18). In line with this, explained Sanjaya (2014: 147) that the learning method is a method used to implement plans that have been compiled in real activities so that the goals that have been prepared are achieved optimally. Smaldino et al (2008: 15) explain that the learning method is a process or procedure used by teachers or instructors to achieve goals or potential.

Improper application of learning methods will lead to boredom for students in receiving the material presented so that the material cannot be understood which will result in students becoming apathetic. Therefore, teachers are not only required to have the knowledge and ability to teach, but also to realize the complexity of roles according to the tasks and functions they carry out creatively (Agung, 2010: 23). In addition, the research results also show a significant relationship between the application of learning methods and learning outcomes, including: (1) research by Hamida (2014), Fartati (2014) and (3) Trisnawaty and Slameto (2017).

Another factor that is not less important is the learning activity itself. In the learning activities carried out by students, the intention is that in addition to strengthening it also creates a positive attitude towards learning Islamic Religious Education. For a teacher, giving birth to a positive attitude is very important for all subjects, including the subject of Islamic Religious Education. Because with this positive attitude, love or liking for certain 
subjects will emerge. And automatically a sense of love or love for certain subjects will generate excitement for students to study them.

This means that learning activities that he does related to subjects he likes will also increase. For example, students will learn even though there is no teacher in the class, they will repeat or study material that has been or has not been studied even though no one instructs it, makes a summary, underlines the material that is considered important, prepares learning equipment that will be used the next day. , and so forth. This is supported by the results of previous studies that show the positive influence of learning activities on learning outcomes, including: Hamzah and Mahampang (2016), Sarianti, Aminuyati, and Syahrudin (2016) and Nuraini, Fitriani and Fadhilah (2018).

Based on the explanation above, the research is interested in revealing the contribution of the application of learning methods and learning activities to student learning outcomes of Islamic Religious Education.

\section{Research Methods}

This research is a quantitative study with correlation research methods with the aim of describing three things, namely: (1) the contribution of the variable of the application of the learning learning method $\left(\mathrm{X}_{1}\right)$ to the learning outcomes variable of Islamic Religious Education $(\mathrm{Y}),(2)$ the contribution of the learning activity variable $\left(\mathrm{X}_{2}\right)$ with the learning outcomes variable of Islamic Religious Education (Y), and (3) the contribution of the application of the learning method $\left(\mathrm{X}_{1}\right)$ and the learning activity variable $\left(\mathrm{X}_{2}\right)$ with the learning outcome variable (Y).

The population in this study was all students of class VIII which consisted of 2 classes with a total of 72 . All students were used as research samples. The data collection instruments used was questionnaires and tests. The data analysis used is correlation and regression.

\section{Results And Discussion}

Based on the trend test, the variable data application of the learning method carried out by the teacher showed a high category with a score range $\geq 78$ at $18.05 \%$ and a moderate category with a score range of 60 to 77 of $1.39 \%$ and a less category of $80.56 \%$. Thus, the tendency in the application of the learning method category is lacking, this fact is a fact that must be considered and followed up by the Principal to provide guidance to teachers on an ongoing basis so that the application of learning methods owned by teachers can be improved in the future.

Furthermore, if we pay attention to the indicators forming the application of learning methods in the aspects of: planning the application of learning methods, implementing the application of learning methods and conducting evaluations, then the aspect of implementing the application of learning methods still looks weak. This fact shows that the application of learning methods according to respondents, in this case the teacher is weak, is dominated by weakness and deficiency factors in implementing the application of learning methods to teachers.

In fact, this gives a signal to the Principal to provide guidance to teachers, especially in providing guidance on the roles and functions that must be carried out optimally by the teacher through the implementation of the application of learning methods. The pattern of coaching carried out by the Principal through coordination meetings and class visits is further intensified. 
It is hoped that through coordination meetings and class visits, it is hoped that teachers will be able to carry out their roles and functions in carrying out teacher duties so that teachers can carry out their functions and duties as well as possible as explained by Kimball Wiles in (Gunawan 2006: 194). The learning method is intended to observe, assess to find out the shortcomings or weaknesses of the teacher so that the teacher's ability can be assisted and developed in the subsequent teaching and learning process. Thus, the role of the principal in carrying out supervision is very much needed by teachers to improve the quality of teachers in carrying out learning activities.

Based on the trend test, the student learning activity variable shows high, moderate, less and low categories as follows: high category with a score range $\geq 75$ is $16.67 \%$ and medium category with a score range of 58 to 74 of $58.33 \%$, while less with a score range of 40 to 57 of $25.00 \%$. Based on the trend, these data indicate that the trend in student learning activities is in the moderate category.

Furthermore, if we pay attention to the indicators that form learning activities, namely aspects: motivation for learning activities, learning activities, benefits obtained, and follow-up, then the follow-up aspect still looks weak. Although the overall category of learning activity tendency is high, there is a fairly high percentage in the medium category, namely $58.33 \%$. This fact shows that there are still weaknesses in the respondent's learning activities mainly dominated by weaknesses and deficiencies in the follow-up aspect.

In fact, this gives a signal to the teacher to conduct intensive and continuous coaching of student learning activities by scheduling continuous learning activities. This is important to note because through good learning activities as one of the factors to improve student learning outcomes.

Based on the trend test, the variable data on the learning outcomes of students' Islamic Religious Education showed high, moderate, less and low categories as follows: high category with a score range $\geq 88$ was $45.83 \%$, medium category with a score range of 68 to 87 of $54.17 \%$, while there are no low and low categories. Based on the trend, these data indicate that the majority of students have a tendency for the learning outcomes of Islamic Religious Education to be in the moderate category.

The first finding shows that there is a positive and significant contribution contribution between the application of the learning method and the student learning outcomes of Islamic Religious Education with a correlation number of 0.354 . The application of the learning method also gave an effective contribution to the learning outcomes of students' Islamic Religious Education with a figure of $9.90 \%$. This data creates opportunities for teachers to activate the application of better learning methods so that there is an increase in student learning outcomes of Islamic Religious Education. Adequate application of learning methods by the teacher will give birth to student learning activities which are expected to achieve maximum learning outcomes of Islamic Religious Education.

The explanation above is in line with Briggs and Justman as cited by Gunawan (2006:193) which explains the application of learning methods as a systematic and continuous effort to encourage and direct learning more effectively in helping achieve educational goals with students under their responsibility in achieving results. learn the maximum Islamic Religious Education.

The appropriate learning method applied by the teacher in the classroom is expected that students are truly involved in learning activities and provide more opportunities for students to gain awareness and develop their self-concept better and also develop individual abilities. Students should be encouraged to solve problems in group or individual work. In this case, the teacher is a resource person whose job is to provide the 
assistance needed to ensure and direct students in achieving the specified learning objectives.

Learning Islamic Religious Education as one of the subjects given to students has a fairly broad scope and has different characteristics from other subjects, because the teaching material in the Islamic Religious Education subject is related to religious teachings which are not only required for cognitive mastery. but more than that as a religious teaching, it is practiced in everyday life.

Learning is said to be successful determined by various factors, including factors related to the application of learning methods carried out by the teacher. The optimal learning outcomes of Islamic Religious Education can be achieved through various efforts made by the teacher, one of which is the application of more meaningful learning methods where through these learning methods students are able to find themselves the knowledge and skills they need, not because they are told by the teacher alone but students are able to construct. own knowledge in his mind. The application of learning methods in the learning process requires full involvement from students and teachers both mentally and emotionally. Having mental and emotional involvement in the learning process will enable learning goals to be achieved and effective learning outcomes.

Teachers are expected to have knowledge and understanding of learning methods in the implementation of learning because knowledge and understanding of learning methods is important as an effort to provide experience and achieve optimal student learning goals. So to determine an effective learning method in teaching teaching material it is estimated from the possibility that it can arouse students' mental involvement in learning.

Learning methods that are appropriately applied in the classroom are expected to be really involved in students in learning activities and provide more opportunities for students to gain awareness and develop their self-concept better and also develop individual abilities. Students should be encouraged to solve problems in group or individual work. In this case, the teacher is a resource person whose job is to provide the assistance needed to ensure and direct students in achieving the specified learning objectives.

Learning Islamic Religious Education as one of the subjects given in elementary schools has a fairly broad scope and has different characteristics from other subjects, because the teaching material in the Islamic Religious Education subject is related to religious teachings which are not only required cognitive mastery. but more of these religious teachings are practiced in everyday life.

Therefore, achieving this, of course, requires different teacher skills in teaching students in this Islamic Religious Education subject. Teachers must use effective and efficient learning methods so that learning can achieve the desired results. In addition, learning objectives will be easily achieved if students are motivated to learn.

The findings of this study reinforce the results of previous research including: (1) Kambe's research (2013) shows that through demonstration methods it can improve student learning outcomes in mathematics in grade V SD Negeri 1 Balingara on the volume of cubes and blocks. In the initial test of students who completed 5 people (percentage of classical complete $33.33 \%$ ) and classical absorption of $57 \%$, (2) research by Dahyana (2014) showed that student learning outcomes in the first cycle were in the sufficient category (mean 69.20) but has not achieved the expected learning completeness. In the second cycle, student learning outcomes were in a very good category (average 81.40 ). The improvement of student learning outcomes through the demonstration method is supported by an increase in student learning activities, in the form of: activeness of recording subject matter, showing a critical attitude in questioning with students and teachers, activeness of 
conducting demonstrations, and activeness of concluding subject matter, (3) Subrata's research (2016) shows that there is an increase in student activity that can be seen based on self-assessment and observers in cycle I and cycle II, from $87.3 \%$ to $96.3 \%$. While the increase in classical learning completeness in cycles I and II is from $59.4 \%$ to $87.5 \%$. Based on the results of this study, it can be concluded that the use of the demonstration method can increase student activity in learning and learning outcomes, and (4) Umiatik's research (2017) shows the application of varied methods in mathematics and Indonesian in grade I of SD Negeri 015 Sungai Sirih District. Singingi, Kuantan Regency can improve student learning activities and student learning outcomes.

As with the application of learning methods, student learning activities also show a positive and significant contribution to the learning outcomes of Islamic Religious Education with a correlation magnitude of 0.473 . This shows that the category of contribution between learning activities and student learning outcomes of Islamic Religious Education is medium category. The effective contribution given by the learning activity variable to learning outcomes was $20.00 \%$. This data creates opportunities for teachers to improve programs or activities related to student learning activities.

Achieving high student learning outcomes of Islamic Religious Education cannot be done in a routine learning process only. Students must be placed as learning subjects, not as learning objects. As a learning subject, it means that students are actively involved in the learning process, where students are given the widest possible space and time to carry out their learning activities. For example, students actively discuss, study independently, summarize lessons, seek information, carry out investigations, and provide evidence.

This will have an impact on the learning outcomes he will get. Conversely, if students are positioned as learning objects, it means that students are not actively involved in the learning process, where they only listen a lot to what the teacher says. Therefore, this condition will cause low learning outcomes. Learning is at the core of the overall educational process, with teachers as the main role. In the learning process, there are a series of actions of teachers and students on the basis of reciprocal relationships that take place in educational situations to achieve certain goals.

This interaction or reciprocal relationship between teachers and students is the main requirement for the ongoing learning process besides educational interactions that also have on the learning process. In this case the teacher is not only a material for delivering subject matter, but as a conveyor in order to achieve learning outcomes and attitudes in students who are learning.

Achieving high student learning outcomes cannot be done in a routine learning process only. Students must be placed as learning subjects, not as learning objects. As a learning subject, it means that students are actively involved in the learning process, where students are given the widest possible space and time to carry out their learning activities.

For example, students actively discuss, study independently, summarize lessons, seek information, carry out investigations, and provide evidence. This will have an impact on the learning outcomes he will get. Conversely, if students are positioned as learning objects, it means that students are not actively involved in the learning process, where they only listen a lot to what the teacher says. Therefore, this condition will cause low learning outcomes.

The learning method used by the teacher will be able to influence the level of achievement of student learning outcomes. The use of appropriate learning methods and in accordance with student characteristics will provide good learning outcomes as well. Therefore it is not easy for a teacher to be able to attract students' interest and attention in learning Islamic Religious Education teaching materials. 
Teachers must be able to apply appropriate learning methods for students who have different characteristics. The teacher's inability to design and implement learning methods that are in accordance with student characteristics will result in difficulty for students to digest the material given. In addition, it will also cause boredom in the learning process. This will have an impact on not achieving the learning objectives to obtain effective and efficient results.

The desire of students to do a learning activity with all the efforts they have, because in a person there is such great strength and energy. Therefore, independence is the psychological aspects that are owned by each individual. Independence is a force (power), power (energy), or a complex state (a complex state) and readiness (preparatory set) within the individual (organism) to move (to move, motion, motive) towards a specific goal, whether consciously or unconsciously.

The task of the teacher must always be to develop optimal student learning independence in the learning process. Because in each student there is stored power, forces, energy, or a complex state and a preparatory set within the individual (organism) to move (to move, motion, motive) to carry out their learning activities.

The position of the learning method with the success of a student in learning is very close and cannot be separated. The more varied the application of learning methods by the teacher, the students, the greater the effort they make to achieve their learning success. Because the independence in a person becomes a motor (motor) that will activate all the available energy, including learning activities. Thus, it can be stated that independent learning has a positive and significant relationship with student learning outcomes.

In addition, the learning process, the activities and activities of the teacher, are the most decisive in the learning process so that students have knowledge of what is being learned. In addition, it is to arouse students' interest and independence to want to learn voluntarily. This activity is the most important thing that must be built at this preliminary stage. The creation of such conditions is very important before starting learning, because in essence learning activities are activities related to the physical and mental state of a student.

The main task that the teacher must do in learning is to increase student activity in learning. Conversely, minimizing the space for teachers in teaching activities, because by increasing learning activities, students will better understand what they are learning, for example, taking notes, making summaries, actively asking and answering questions from the teacher, conducting investigations, collecting data, and conducting tests. . With these learning activities, it is possible that learning outcomes will be better.

Likewise with the application of learning methods which are external (external) and internal (internal) forces that underlie students in carrying out their learning activities. High learning activities will give birth to a serious attitude in learning which is marked by persistence in doing the assignments given by the teacher, discipline with learning time, concentration in learning and so on. If this is done correctly and consistently, it will have an impact on increasing learning outcomes obtained by students.

The findings of this study confirm the results of previous research, including: (1) the results of research by Hamzah and Mahmud (2016) show that learning activities have a positive effect on students' understanding of mathematical concepts. This is indicated by the value of the correlation coefficient is 0.924 which indicates a high level of correlation. And for the coefficient of determination is $85.4 \%$ which means that the effect of learning activities on students' understanding of mathematical concepts is $85.4 \%$, while the remaining $14.6 \%$ is influenced by other factors besides the learning activities studied in the study, (2) the results of research by Nurmala, Ripalup and Suharsono. (2014) show that 
learning activities have an effect on the learning outcomes of class $\mathrm{X}$ accounting students at SMK Negeri 1 Singaraja in the 2013/2014 academic year. This can be seen from tcount $=5.742>$ ttable $=1.658$ or significant count $=0.000<$ from $\alpha=0.05$. So the hypothesis which states that there is a positive and significant influence between learning activities on learning outcomes of class $X$ accounting students at SMK Negeri 1 Singaraja in the academic year 2013/2014 is proven and acceptable. Thus, student learning activities have an effect on the achievement of learning outcomes, (3) Ekawati's research results (2016) show that learning activity variables have a positive effect on student mathematics learning outcomes with a t-count value of 2.398 and a probability value of 0.018 . Because the value of $0.018<0.05$, Ho is rejected, which means that the learning activity variable has a positive effect on mathematics learning outcomes, and (4) the results of Mintarti's (2016) research show that there is a significant effect of learning activities on the social studies learning achievement of class IX students of SMPN 4 Probolinggo City., which is indicated by the probability tcount for the learning activity variable is 0,000 which is smaller than $\alpha=0.05$.

If it is examined further about the effective contribution of the two variables, namely the variable application of learning methods and learning activities to student learning outcomes, the greater the contribution is learning activities. This is because learning outcomes are determined by the presence of high learning activities to carry out the duties and functions inherent in the teacher.

The application of learning methods and learning activities together shows a positive and significant relationship with student learning outcomes with a correlation magnitude of 0.549 and the effective contribution given to the application of learning methods and learning activities together on learning outcomes is $30.20 \%$. This means that there are more factors that can support learning outcomes that were not examined in this study.

\section{Conclusion}

The conclusions that can be drawn from the research findings are as follows: (1) there is a positive and significant contribution between the application of learning methods and student learning outcomes, meaning that the higher and more positive the application of learning methods, the higher and more positive the student learning outcomes by making an effective contribution of $9.90 \%$, (2) there is a positive and significant contribution between learning activities and student learning outcomes, meaning that the higher and more positive learning activities, the higher and more positive the learning outcomes by providing an effective contribution of $20.00 \%$, and (3) there is a positive and significant contribution together between the application of learning methods and learning activities with student learning outcomes, meaning that the higher and more positive the application of learning methods and learning outcomes, the higher and more positive the learning outcomes by making an effective contribution of $30.20 \%$.

Recommendations that can be given are: (1) Principals to provide instructions for teachers to apply continuous learning methods through coordination meetings and class visits and provide opportunities for teachers to develop their potential to attend higher education or participate in training, (2) Teachers are expected to be able to apply various learning methods because through this it is expected to increase student learning activities which in turn can improve student learning outcomes, and (3) To other researchers that this research needs to be followed up, especially with regard to different variables. which also contributes to learning outcomes. 


\section{References}

Ananda, Rusydi. (2019). Perencanaan Pembelajaran. Medan: LPPPI.

Arsani, et al. (2020). Differences in Motivational Orientation in Physical Education in terms of Gender Differences. Budapest International Research and Critics in Linguistics and Education (BirLE) Journal. P. 1428-1434.

Dahyana, Penerapan Metode Demonstrasi Untuk Meningkatkan Hasil Belajar Siswa Dalam Pembelajaran IPAa Terpadu, Jurnal: Nalar Pendidikan Volume 2, Nomor 2, Juli-Desember 2014

Ekawati, Shindy. (2016). Pengaruh Kedisiplinan Dan Aktivitas Belajar Terhadap Hasil Belajar Matematika Siswa. Jurnal: Pedagogy Volume 1 Nomor 2.

Fartati. Penerapan Metode Demonstrasi Untuk Meningkatkan Hasi Belajar Siswa Pada Materi Penyebab Benda Bergerak Di Kelas II SD No. 1 Polanto Jaya. Jurnal: Kreatif Tadulako Vol. 3 No. 3

Hamidah. (2014). Penggunaan Metode Demonstrasi Drill Untuk Meningkatkan Prestasi Belajar Pada Materi Berwudlu Siswa Kelas Ii Sdn Manggisan 01 Kecamatan Tanggul Kabupaten Jember. Jurnal: Pancaran, Vol. 3, No. 4, hal 59-68, Nopember

Kambe,Sanawati, Rizal, Muh. dan Hasbi, Muh. Penerapan Metode Demonstrasi Untuk Meningkatkan Hasil Belajar Siswa Kelas V SDN 1 Balingara Pada Materi Volume Kubus Dan Balok. Jurnal Kreatif Tadulako Online Vol. 5 No. 2 ISSN 2354-614X

Mintarti, Susetyo Budi. (2016).Pengaruh Gaya Belajar Visual Dan Aktivitas Belajar Terhadap Prestasi Belajar Siswa Kelas IX Di SMP Negeri 4 Kota Probolinggo. Jurnal: Penelitian dan Pendidikan IPS (JPPI) Volume 10 No 1.

Nuraini, Fitriani dan Fadhilah, Raudhatul. (2018). Hubungan Antara Aktivitas Belajar Siswa Dan Hasil Belajar Pada Mata Pelajaran Kimia Kelas X Sma Negeri 5 Pontianak. Jurnal: Ar-Razi Vol. 6 No. 1, Februari.

Nurmala, Desy Ayu, Tripalupi, Lulup Endah dan Suharsono, Naswan. (2014). Pengaruh Motivasi Belajar Dan Aktivitas Belajar Terhadap Hasil Belajar Akuntans.i Jurnal: Pendidikan Ganesha Vol: 4 No: 1 Tahun.

Prawiradilaga. Dewi. S. (2007). Prinsip Desain Pembelajaran. Jakarta: Universitas Negeri Jakarta.

Sanjaya, Wina. (2014). Strategi Pembelajaran, Berorientasi Standar Proses Pendidikan. Jakarta: Prenada Media Group.

Simorangkir, F and Sembiring, R. (2018). Effectiveness of Helped Mathematical Learning Media of Lectora Inspire on The Number Sense Ability of Fifth Grade Students of Elementary School in Substrate Materials. Budapest International Research and Critics Institute-Journal (BIRCI-Journal). P. 352-358.

Smaldino, Sharon E., Lowther, Deborah L. dan Russell, James D. (2008).Instructional Technology and Media for Learning. Ninth Edition. New Jersey: Pearson Prentice Hall.

Trisnawaty, Fikria dan Slameto. (2017). Peningkatkan Hasil Belajar Ipa Melalui Penggunaan Metode Demonstrasi Pada Siswa Kelas 4 SD. Jurnal: Satya Widya, Vol. 33, No. 1. Juni: 37-44

Umiatik, Tri.( 2017). Penggunaan Metode Demonstrasi Untuk Meningkatkan Pemahaman Konsep Bangun Ruang Dan Kemampuan Membaca Pada Siswa Sekolah Dasar. Jurnal: Suara Guru, Jurnal Ilmu Pendidikan Sosial, Sains, dan Humaniora Vol. 3 No. 3, September. 